\title{
The physical characteristics of cheese made of milk, colostrum and both during the ripening
}

\author{
F. D. Astuti ${ }^{1,2}$, T. Setyawardani ${ }^{2, *}$ and S. S. Santosa ${ }^{2}$ \\ ${ }^{1}$ Department of Livestock and Animal Health, Central Java Province, \\ Kompleks Tarubudaya, Jl. Gatot Subroto, Ungaran, Semarang -Indonesia \\ ${ }^{2}$ Faculty of Animal Science, Universitas Jenderal Soedirman, \\ Jl. Dr. Soeparno No. 60 Karangwangkal, Purwokerto - Indonesia \\ *Corresponding E-mail: triana.setyawardani@unsoed.ac.id
}

Received October 24, 2020; Accepted December 28, 2020

\begin{abstract}
ABSTRAK
Penelitian ini bertujuan untuk mengetahui karakteristik fisik keju yang dibuat dari susu sapi, kombinasi susu dan kolostrum dan kolostrum yang diperam selama 20 hari. Keju dibuat dengan tiga jenis bahan baku yaitu: A (100\% susu), B (50\% susu $+50 \%$ kolostrum) dan C (100\% kolostrum) sebagai faktor pertama dan lama pemeraman 0 hari, 10 hari dan 20 hari sebagai faktor kedua. Proses produksi keju diawali dengan pemanasan bahan baku, penurunan suhu dan penambahan kefir sebagai starter, dilakukan inkubasi selama 2 jam sampai $\mathrm{pH}$ menjadi 6,2. Tahapan selanjutnya adalah penambahan rennet dan inkubasi kembali selama 1 jam sampai terbentuk gumpalan padat, dilakukan penyaringan dan pengepresan. Keju disimpan pada suhu dingin $\left(4-8^{\circ} \mathrm{C}\right)$ sesuai dengan perlakuan. Setiap kombinasi perlakuan diulang sebanyak 3 kali. Variabel fisik keju meliputi warna, profil tekstur, $\mathrm{pH}$, dan mikrostruktur. Bahan baku keju menghasilkan perbedaan warna keju meliputi kecerahan (L*), kekuningan $\left(b^{*}\right)$, dan derajat putih (WI) dan profil tekstur keju yaitu hardness, gumminess demikian juga dengan lama penyimpanan mempengaruhi hardness, springiness, gumminess, chewiness, $L^{*}, a^{*}$, dan WI keju. Kolostrum yang yang digunakan meningkatkan warna kekuningan keju tetapi semakin banyak rongga kosong pada mikrostrukturnya.
\end{abstract}

Kata kunci : kolostrum, warna, tekstur, mikrostruktur, keju

\section{ABSTRACT}

This study aimed to understand the physical characteristics of cheese made of cow milk, colostrum, and milk+colostrum ripened for 20 days. Two factors in this study were cheese made of three materials: A ( $100 \%$ cow milk), B (50\% cow milk $+50 \%$ colostrum) and C (100\% colostrum), and ripening time, i.e. 0,10 , and 20 days. The process of cheese production started by heating the raw material, followed by decreasing the temperature, incorporating kefir as the starter. The next step was and the rennet and reincubate the mixture for one hour until the fluid became solid granules, then the granules were filtered and pressed. The cheese was stored at a low temperature $\left(4-8^{\circ} \mathrm{C}\right)$ according to each treatment. Each combination was repeated three times. The physical properties of cheese examined in this study were color, texture, $\mathrm{pH}$, and microstructure. The result showed that the raw materials of cheese would produce different cheese colours in terms of lightness $\left(\mathrm{L}^{*}\right)$, yellowness $\left(\mathrm{b}^{*}\right)$, and whiteness index (WI) as well as cheese texture (hardness and gumminess). Also, ripening time would affect the hardness, springiness gumminess, chewiness, $\mathrm{L}^{*}, \mathrm{a}^{*}$, and WI of cheese. Colostrum added in cheesemaking has increased both 
yellowness and cavities in the microstructure.

Keywords: colostrum, color, texture, microstructure, cheese

\section{INTRODUCTION}

Cheese produced from indirect acidification uses lactic acid bacteria (LAB) as the starter that plays a vital role in decreasing milk $\mathrm{pH}$. LAB may derive from kefir and, together with some yeasts, would dominate the kefir metabolism product. Previous studies used kefir as the source of LAB for cheese production and reported that kefir would affect the physical properties of cheese during ripening Studies on cheese characteristics using kefir as a starter have been conducted, namely wet/liquid kefir for white pickled cheese (Goncu and Alpkent, 2005; et al., 2006), freezedried kefir for feta cheese for people with high blood pressure (Kourkoutas et al., 2006) and freeze-dried Tibetan kefir for Bod Ijong cheese (Mei et al., 2015). Based on these studies, it is evident that kefir as cheese starter could produce cheese with marketable properties (Kourkoutas et al., 2006; Mei et al., 2015), including the more preferable $\mathrm{pH}$ (acidity), appearance, structure, and aroma compared to cheese made of commercial and yoghurt starters (Goncu and Alpkent, 2005).

According to Setyawardani et al. (2020) colostrum has lower $\mathrm{pH}$, higher density, a rich, yellow color, and thicker viscosity than cow milk. The different physical characteristics between colostrum and cow milk would produce cheese with contrast characteristics. Cheese incubation would change the cheese characteristics, particularly the physical properties. The longer the incubation, the cheese would become more yellow and the surface is drier which also affects the texture. Considering the lack of investigation on cheese made of colostrum, the researchers conducted a novel examination of the physical characteristics of cheese made of different raw materials. Colostrum is postpartum fluid discharge containing high nucleic acid, amino acid derivatives, protein, fat and mineral (PeckaKiełb et al., 2018). Additionally, colostrum contains lactalbumin, lactal protein, and an antibody that plays a role in maintaining body immune, lactalbumin, and lactoprotein (Godhia and Patel, 2013). Combined with the Bifidobacteria group of probiotics, colostrum would make a potential functional food (Hyrslova et al., 2016).

Most cheese is made of milk from cow, goat, or buffalo. Buffalo milk or Dangke is a local cheese from Indonesia (Al-Baarri et al., 2018). The present study incorporated colostrum as the raw material in different percentages, i.e. 0, 50, and $100 \%$ and kefir as the starter. Cheese starter generally consists of lactic acid bacteria; however, some studies use kefir because it contains a more complex microflora than that of LAB starter, thus producing cheese with enhanced characteristics. As cheese starter, lactic acid and yeast combined in kefir provide many benefits.

Cheese generally undergoes both physical and chemical changes during ripening. The evident physical change includes hardening texture and color change. Also, proteolysis occurs during incubation which affects the $\mathrm{pH}$ level, color, texture profile, and microstructure. When ripened in the right condition, cheese would have a softer texture but not fragile and a perfect flavor (Setyawardani et al., 2017a). The hypothesis of this study is that cheese made of colostrumenriched ingredient has a more yellow color, a more compact texture, and a longer incubation that affects its physical characteristics. This study aimed to examine the physical characteristics of cheese made of milk, colostrum, and both, under different incubation times.

Therefore, studies that combine raw materials and ripening in cheesemaking have become interesting in investigating investigate cheese's physical properties.

\section{MATERIALS AND METHODS}

The cheese was made of colostrum and cow milk obtained from The National breeding center for dairy cattle and forage (BBPTU-HPT Baturraden). The colostrum was the combination of colostrum milked on the second-, and third-day post-partum. The other materials were kefir grains, commercial vegetable rennet (Danisco), colorimeter (CHNSpec, CS-10, China), Texture Profile Analyzer (Ametek, TA-1, UK), SEM (JEOL JSM-IT 200), and container for cheese ripening.

\section{Cheese Making}

Cheese was made of three raw materials: A ( $0 \%$ colostrum or $100 \%$ fresh fresh cow milk), B (50\% fresh cow milk and 50\% colostrum), C 
(100\% colostrum). Colostrum and fresh cow milk was pasteurized differently $\left(60^{\circ} \mathrm{C}\right.$ for $10 \mathrm{~s}$ and $62^{\circ} \mathrm{C}$ for 30 mins, respectively) and cooled to reach $40^{\circ} \mathrm{C}$. Kefir starter ( $5 \%$ of total milk) was added until the milk pH was 6.1. Next, the rennet was added $(0, .5 \mathrm{~g} / \mathrm{L}$ milk $)$ and re-incubated to obtain the perfect curdling. The curd cheese yield was chopped and heated at $40^{\circ} \mathrm{C}$ for 10 mins. The curd was then separated from the liquid through filtering. The curd was pressed to obtain the least water content in the curd, and then cheese was ripened for 20 days (Setyawardani et al., 2019; Sumarmono et al., 2020). Each batch was repeated three times.

\section{Testing Milk as Raw Materials}

The composition of raw materials (milk and colostrum) was examined using a milk analyzer (Lactostar 3510, Funke Gerber, Germany).

\section{pH Measurement}

$\mathrm{pH}$ value was measured using a digital $\mathrm{pH}$ meter (Sharp, Japan). A $10 \mathrm{~g}$ of cheese sample was incorporated into $10 \mathrm{~mL}$ aquadest (Setyawardani et al., 2019). pH measurement was conducted three times in every sample.

\section{Texture Measurement}

The cheese texture was observed using a texture profile analyzer (Ametek, United Kingdom). The cheese sample was conditioned at room temperature for 15 mins prior to measurement, then the cheese was cut in a cylindrical shape with a diameter and height of $1.7 \mathrm{~cm}$. The probe was $3.5 \mathrm{~cm}$ in diameter with a $50 \%$ pressure ratio and $1 \mathrm{~mm} / \mathrm{s}$ loading rate (Ong et al., 2011).

\section{Color Measurement}

The cheese color was tested using a colorimeter (CS-10, CHNSpec, China) with a CIE color scale (International Commission on Illumination). Color testing was based on the coordinate of $\mathrm{L}^{*}, \mathrm{a}^{*}$, and $\mathrm{b}^{*}$ (El-Nimr et al., 2010). The whiteness index (WI) was calculated using the formula WI $=\left(\left(100-\mathrm{L}^{* 2}\right)+\mathrm{a}^{* 2}+\mathrm{b}^{* 2}\right)^{1 / 2}$

\section{Microstructure Observation}

The microstructure of cheese was observed using an SEM (Scanning Electron Microscope type JEOL JSM-IT 200). As much as 5-6 $\mathrm{mm}^{3}$ cheese sample was incorporated into a $4 \% \mathrm{w} / \mathrm{v}$ glutaraldehyde in a phosphate buffer with $\mathrm{pH} 7.2$ for $12 \mathrm{~h}$ at $40^{\circ} \mathrm{C}$. Then, the sample was cleaned using $0.1 \mathrm{M}$ cocodylate buffer for 10 mins, three times. The next step was dehydration using five solutions of ethanol i.e 50,70, 85, 95, and $100 \%$ $\mathrm{v} / \mathrm{v}$. After that, the cheese was freeze-dried and coated with a golden coating (Setyawardani et al., 2017b). Cheese microstructure was observed under an electron microscope with 100 and $500 \times$ magnification.

\section{Data Analysis}

The data were collected and displayed based on the average \pm standard deviation. Cheese $\mathrm{pH}$, color, and structure profile were the variables subjected to statistical analysis in a General Linear Model (GLM), and each treatment was repeated 3 times.

\section{RESULTS AND DISCUSSION}

\section{The Composition of Cheese Raw Materials}

The analysis result of the composition of raw materials for cheese using a milk analyzer is presented in Table 1 . The chemical and physical properties of milk in this study were higher than those in Indonesia National Standard (SNI), thus suitable for cheese making. Also, milk and colostrum combined as the raw material for cheese exhibit better chemical and physical properties than those in SNI. Therefore, cheese and colostrum can increase cheese quality, especially physical characteristics. The quality of raw material is one of the contributing factors to overall cheese quality. This study confirms that colostrum contains better chemical composition than fresh milk. Table 1 shows that colostrum has higher protein, lactose, SNF, and fat than milk and it is expected to produce better quality cheese as an innovative cheese product. The higher level of casein in colostrum would improve the cheese texture.

\section{Cheese pH}

Cheese ripened for 20 days produced the highest $\mathrm{pH}$ of all cheese made of different raw materials. Fermentation time also resulted in different $\mathrm{pH}$ values across cheese yields $(\mathrm{P}<0.05)$. The increased cheese $\mathrm{pH}$ was observed across raw materials where the $\mathrm{pH}$ of cheese without fermentation increased from 4.31 to 4.59 on day-10, and continued to reach 5.19 on day-20. Cheese $\mathrm{B}$ had $\mathrm{pH} 3.96$ at the initial ripening and increased to 4.04 on day-10 and 4.75 on day 20 . Meanwhile, the $\mathrm{pH}$ of cheese $\mathrm{C}$ on 0,10 , and 20day of ripening was 4.12, 4.10, and 4.89, 
Table 1. Cheese Raw Material Composition

\begin{tabular}{lccc}
\hline \multicolumn{1}{c}{ Composition } & Fresh Milk & Colustrum & $\begin{array}{c}\text { Indonesian National } \\
\text { Standard (SNI), 2011 }\end{array}$ \\
\hline Fat (\%) & 4.59 & 6.99 & Min 3.0 \\
Protein (\%) & 3.12 & 11.77 & Min 2.8 \\
Casein (\%) & - & 5.59 & - \\
Solid non Fat (\%) & 8.56 & 18.72 & Min 7.8 \\
Lactose (\%) & 4.69 & 10.22 & - \\
Mineral (\%) & - & 0.61 & - \\
pH & 6.7 & 6.6 & $6.3-6.8$ \\
Specific grafity $(\mathrm{g} / \mathrm{mL})$ & 1.0284 & 1.0517 & 1.027 \\
\hline
\end{tabular}

respectively (Table 2).

Cheese $\mathrm{pH}$ would increase from the start to the end of ripening. Lactic acid bacteria were trapped in the cheese matrix and able to stabilize cheese $\mathrm{pH}$; therefore, the longer the ripening, the higher the cheese $\mathrm{pH}$. Yeast could grow naturally during ripening and help increase cheese $\mathrm{pH}$ at the end of the process. This result was confirmed by previous studies (Sadowska et al., 2009; Setyawardani et al., 2017b; Todaro et al., 2017) that cheese $\mathrm{pH}$ declines at the start of ripening but would keep increasing due to the diminishing production of lactic acid bacteria and alkali effect produced by yeast during ripening.

\section{Cheese Texture Profile}

Cheese hardness before and during ripening was varied; it decreased on the $10 \mathrm{t}^{\mathrm{h}}$ day but increase at the end of $20^{\text {th }}$ day. The raw materials for cheesemaking have significantly affected $(\mathrm{P}<0.05)$ hardness. The highest hardness value was in cheese A $(16.18 \mathrm{~N})$ followed by cheese C $(10.00 \mathrm{~N})$ and cheese B (8.99) (Table 3). Similarly, ripening time also affected cheese springiness. Before ripening, the springiness index of cheese was $0.75 \mathrm{~mm}$ which decreased to $0.69 \mathrm{~mm}$ after 10-day fermentation until the end of 20-day fermentation (Table 2). However, raw materials did not significantly affect $(\mathrm{P}>0.05)$ cheese cohesiveness, which ranged from 0.37 to $0.43 \mathrm{~N}$. On the contrary, cheese gumminess was significantly affected by raw materials and ripening time $(\mathrm{P}<0.05)$. The highest gumminess during 20 -day ripening was $\mathrm{A}(10.93 \mathrm{~N})$ followed by $\mathrm{C}(3.91 \mathrm{~N})$, and $\mathrm{B}(3.44 \mathrm{~N})$. Cheese chewiness decreased during 10-day ripening, but increased at the end of ripening which yields $8.67 \mathrm{~N}, 3.11 \mathrm{~N}$ and $2.86 \mathrm{~N}$ for cheese $\mathrm{A}, \mathrm{B}$ and $\mathrm{C}$, respectively.

This study demonstrated that low-fat content in cheese $\mathrm{A}$ resulted in a harder texture than cheese B and C. A contributing factor to cheese texture is fat content which, together with casein, would form a three-dimension matrix and soft but solid cheese curd. Cheese hardness is a factor determined by the fat content of the raw materials. Similarly, (Zheng et al., 2016) reported that lowfat cheese is harder or firmer but less springy than high-fat cheese. Also, cheese texture profile, which is affected by fat homogenization, is evident when chewed (Talbot-Walsh et al., 2018).

Ripening time also affects cheese texture, i.e. hardness, springiness, gumminess, and chewiness except for cohesiveness. One contributing element of ripening that affects cheese texture is high humidity which could decrease water content in cheese and increase water holding capacity $\left(\mathrm{A}_{\mathrm{w}}\right)$ that affects proteolysis. The activity of protease and peptidase enzymes would increase similarly to $A_{w}$ in cheese. Ripening time would stimulate surface evaporation on cheese which makes the cheese harder (Nedomová et al., 2017a). A higher cohesiveness in the stored cheese is beneficial as it keeps the cheese structure intact and not fragile. Cohesiveness is related to an internal bond where the harder cheese tends to have a stronger adhesion and weaker cohesion. It is due to the shift of whey protein concentrate with solid cheese during fermentation/ripening (Sołowiej et al., 2014). 
Table 2. Cheese Made of Milk and Colostrum with Different Ratio and Ripening Time and Their Interaction on $\mathrm{pH}$ and Texture Profile

\begin{tabular}{|c|c|c|c|c|c|c|c|c|}
\hline \multirow{2}{*}{ Properties } & \multirow{2}{*}{$\begin{array}{c}\text { Cheese/ } \\
\text { CT }\end{array}$} & \multicolumn{3}{|c|}{ Ripening/R (day) } & \multirow{2}{*}{ Average } & \multicolumn{3}{|c|}{ Significance } \\
\hline & & 0 & 10 & 20 & & $\mathrm{CT}$ & $\mathrm{R}$ & INT \\
\hline \multirow[t]{3}{*}{$\mathrm{pH}$} & A & $4.31 \pm 0.34$ & $4.59 \pm 0.45$ & $5.19 \pm 0.39$ & $4.70 \pm 0.52$ & $\mathrm{~ns}$ & $*$ & ns \\
\hline & $\mathrm{B}$ & $3.96 \pm 0.74$ & $4.04 \pm 0.73$ & $4.75 \pm 0.58$ & $4.25 \pm 0.70$ & & & \\
\hline & $\mathrm{C}$ & $4.12 \pm 0.46$ & $4.10 \pm 0.63$ & $4.89 \pm 0.43$ & $4.31 \pm 0.50$ & & & \\
\hline Average & & $4.13 \pm 0.49$ & $4.24 \pm 0.59$ & $4.89 \pm 0.43$ & & & & \\
\hline \multicolumn{9}{|l|}{ Texture Profile } \\
\hline \multirow[t]{3}{*}{ Hardness $(\mathrm{N})$} & $\mathrm{A}$ & $17.45 \pm 1.75$ & $10.84 \pm 0.10$ & $20.24 \pm 5.56$ & $16.18 \pm 5.10$ & $*$ & $*$ & ns \\
\hline & B & $11.44 \pm 6.51$ & $3.77 \pm 0.10$ & $11.77 \pm 6.56$ & $8.99 \pm 6.06$ & & & \\
\hline & $\mathrm{C}$ & $11.39 \pm 8.76$ & $7.92 \pm 5.05$ & $10.69 \pm 3.07$ & $10.00 \pm 5.52$ & & & \\
\hline Average & & $13.43 \pm 6.29$ & $7.51 \pm 3.98$ & $14.24 \pm 6.43$ & & & & \\
\hline \multirow[t]{3}{*}{$\begin{array}{l}\text { Springiness } \\
(\mathrm{mm})\end{array}$} & $\mathrm{A}$ & $0.86 \pm 0.27$ & $0.62 \pm 0.01$ & $0.79 \pm 0.25$ & $0.75 \pm 0.11$ & $\mathrm{~ns}$ & $*$ & ns \\
\hline & $\mathrm{B}$ & $0.76 \pm 0.11$ & $0.61 \pm 0.01$ & $0.71 \pm 0.11$ & $0.69 \pm 0.10$ & & & \\
\hline & $\mathrm{C}$ & $0.72 \pm 0.12$ & $0.64 \pm 0.06$ & $0.71 \pm 0.05$ & $0.69 \pm 0.83$ & & & \\
\hline Average & & $0.78 \pm 0.10$ & $0.62 \pm 0.03$ & $0.73 \pm 0.07$ & & & & \\
\hline \multirow[t]{3}{*}{$\begin{array}{l}\text { Cohesiviness } \\
\text { (N) }\end{array}$} & A & $0.48 \pm 0.14$ & $0.29 \pm 0.04$ & $0.53 \pm 0.35$ & $0.43 \pm 0.13$ & $\mathrm{~ns}$ & ns & ns \\
\hline & B & $0.43 \pm 0.14$ & $0.40 \pm 0.01$ & $0.27 \pm 0.17$ & $0.37 \pm 0.13$ & & & \\
\hline & $\mathrm{C}$ & $0.36 \pm 0.11$ & $0.46 \pm 0.03$ & $0.36 \pm 0.11$ & $0.39 \pm 0.09$ & & & \\
\hline Average & & $0.42 \pm 0.12$ & $0.38 \pm 0.08$ & $0.38 \pm 0.15$ & & & & \\
\hline \multirow[t]{3}{*}{ Gumminess $(\mathrm{N})$} & $\mathrm{A}$ & $9.04 \pm 2.37$ & $3.13 \pm 0.37$ & $10.93 \pm 3.68$ & $7.70 \pm 4.15$ & $*$ & $*$ & ns \\
\hline & B & $5.50 \pm 4.63$ & $1.44 \pm 0.05$ & $3.44 \pm 0.05$ & $3.63 \pm 3.60$ & & & \\
\hline & $\mathrm{C}$ & $3.78 \pm 3.24$ & $2.14 \pm 1.08$ & $3.91 \pm 2.02$ & $3.28 \pm 2.16$ & & & \\
\hline Average & & $6.11 \pm 3.84$ & $2.24 \pm 0.93$ & $6.26 \pm 4.59$ & & & & \\
\hline \multirow[t]{3}{*}{ Chewiness $(\mathrm{N})$} & A & $4.55 \pm 2.70$ & $1.94 \pm 0.25$ & $8.67 \pm 3.19$ & $5.05 \pm 3.61$ & $\mathrm{~ns}$ & $*$ & ns \\
\hline & B & $4.51 \pm 4.31$ & $0.86 \pm 0.06$ & $3.11 \pm 3.66$ & $2.83 \pm 3.24$ & & & \\
\hline & $\mathrm{C}$ & $6.26 \pm 4.67$ & $1.33 \pm 0.90$ & $2.86 \pm 1.68$ & $3.48 \pm 3.34$ & & & \\
\hline Average & & $5.11 \pm 3.56$ & $1.37 \pm 0.66$ & $4.88 \pm 3.83$ & & & & \\
\hline
\end{tabular}

Data were presented by average value from three replications. $A=$ cheese made from $100 \%$ cow milk), $B=$ cheese made from $(50 \%$ cow milk $+50 \%$ colostrum) and $\mathrm{C}=$ cheese made from $100 \%$ colostrum. ns: non significant $(\mathrm{P}>0.05) ; *$ significant $(\mathrm{P}<0.05)$; INT $=$ interaction between type of cheese and ripening time

\section{Cheese Color}

Ripening has decreased $\mathrm{L}^{*}$ value of cheese A, B, and C. After being ripened for 20 days, the $\mathrm{L}^{*}$ value of cheese $\mathrm{A}, \mathrm{B}$, and $\mathrm{C}$ was $46.24 \%$, $43.44 \%$, and $43.99 \%$, respectively (Table 3 ). Also, WI score in this study has decreased across cheese
A, B, and C, i.e. 44.17, 38.97, and 37.90, respectively. It demonstrated a linear decrease of $\mathrm{L}$ and WI values. Furthermore, the average redness $\left(\mathrm{a}^{*}\right)$ of cheese $\mathrm{A}, \mathrm{B}$, and $\mathrm{C}$ was evidently increased during ripening $(-4.21 \%,-3.48 \%$, and $-2.85 \%$, respectively) (Table 3 ) which also 
Table 3. Cheese Made from Different Ratio Milk and Colostrum, Ripening Time and Their Interaction on Color

\begin{tabular}{|c|c|c|c|c|c|c|c|c|}
\hline \multirow{2}{*}{ Color } & \multirow{2}{*}{$\begin{array}{c}\text { Cheese/ } \\
\text { CT }\end{array}$} & \multicolumn{3}{|c|}{ Ripening/R(day) } & \multirow{2}{*}{ Average } & \multicolumn{3}{|c|}{ Significance } \\
\hline & & 0 & 10 & 20 & & $\mathrm{CT}$ & $\mathrm{R}$ & INT \\
\hline \multirow[t]{3}{*}{$\mathrm{L}^{*}$} & $\mathrm{~A}$ & $59.64 \pm 1.30$ & $54.54 \pm 4.93$ & $46.24 \pm 2.74$ & $53.48 \pm 6.53$ & $*$ & $*$ & $\mathrm{~ns}$ \\
\hline & $\mathrm{B}$ & $50.26 \pm 7.48$ & $46.72 \pm 3.48$ & $43.44 \pm 2.59$ & $46.72 \pm 3.48$ & & & \\
\hline & $\mathrm{C}$ & $54.65 \pm 3.42$ & $48.80 \pm 0.88$ & $43.99 \pm 2.63$ & $49.14 \pm 5.11$ & & & \\
\hline Average & & $54.85 \pm 5.85$ & $50.02 \pm 4.65$ & $44.56 \pm 2.63$ & & & & \\
\hline \multirow[t]{3}{*}{$a^{*}$} & A & $-5.17 \pm 0.32$ & $-4.47 \pm 0.21$ & $-4.21 \pm 0.46$ & $-4.62 \pm 0.52$ & $\mathrm{~ns}$ & $*$ & ns \\
\hline & $\mathrm{B}$ & $-5.06 \pm 0.32$ & $-4.34 \pm 0.60$ & $-3.48 \pm 0.20$ & $-4.29 \pm 0.72$ & & & \\
\hline & $\mathrm{C}$ & $-4.95 \pm 0.40$ & $-4.06 \pm 0.08$ & $-2.85 \pm 1.53$ & $-3.96 \pm 1.21$ & & & \\
\hline Average & & $-5.07 \pm 0.32$ & $-4.29 \pm 0.21$ & $-3.51 \pm 0.1$ & & & & \\
\hline \multirow[t]{3}{*}{$b^{*}$} & $\mathrm{~A}$ & $9.94 \pm 13.38$ & $12.30 \pm 0.27$ & $14.03 \pm 4.14$ & $12.09 \pm 7.22$ & $*$ & ns & ns \\
\hline & $\mathrm{B}$ & $14.10 \pm 2.66$ & $15.58 \pm 1.90$ & $20.87 \pm 12.41$ & $16.85 \pm 7.11$ & & & \\
\hline & $\mathrm{C}$ & $21.55 \pm 1.70$ & $21.09 \pm 3.83$ & $26.06 \pm 7.47$ & $22.90 \pm 4.91$ & & & \\
\hline Average & & $15.19 \pm 8.55$ & $16.32 \pm 4.41$ & $20.32 \pm 9.17$ & & & & \\
\hline \multirow[t]{3}{*}{ WI (\%) } & A & $56.71 \pm 1.23$ & $52.55 \pm 4.76$ & $44.17 \pm 2.43$ & $51.14 \pm 6.17$ & $*$ & $*$ & ns \\
\hline & B & $47.99 \pm 6.40$ & $44.60 \pm 3.11$ & $38.97 \pm 6.28$ & $43.85 \pm 6.17$ & & & \\
\hline & $\mathrm{C}$ & $51.04 \pm 6.18$ & $47.78 \pm 4.63$ & $37.90 \pm 5.08$ & $43.92 \pm 5.80$ & & & \\
\hline Average & & $51.41 \pm 5.49$ & $47.16 \pm 5.00$ & $40.35 \pm 4.91$ & & & & \\
\hline
\end{tabular}

Data were presented by average value from three replications. $\mathrm{A}=$ cheese made from $100 \%$ cow milk), $\mathrm{B}=$ cheese made from $(50 \%$ cow milk $+50 \%$ colostrum) and $\mathrm{C}=$ cheese made from $100 \%$ colostrum. ns: non significant $(\mathrm{P}>0.05) ; *=$ significant $(\mathrm{P}<0.05)$; INT $=$ interaction between type of cheese and ripening time

demonstrated a linear increase. Ripening time resulted in yellowness of cheese $\left(b^{*}\right)$ that was not significantly different $(\mathrm{P}>0.05)$. However, the raw materials of cheese responded differently to the percentage of yellowness. The more colostrum used in the cheese making, the higher the yellowness score $\left(b^{*}\right)$. Cheese raw materials affected $L^{*}, b^{*}$, and WI values except for $a^{*}$. The lightness and whiteness of cheese are affected by different fat content in the raw materials. Colostrum contains $6 \%$ fat, which is twice as recommended by SNI 2011. The yellow colours in colostrum hints at beta carotene pigment, so the cheese produced is dark yellow which affects the lightness $/ \mathrm{L}^{*}$ of the cheese. Similarly (Shendi et al., 2010) reported that cheese produced from full-fat milk would have a lower lightness level (L*) than that of low-fat milk. Therefore, the yellow color in cheese is attributed to fat content and beta carotene in the milk. Carotene pigment in milk is responsible for the yellowish and reddish color in cheese (Pinho et al., 2004).

Cheese ripening would decrease lightness and whiteness index (Nedomová et al., 2017b) stated that cheese lightness $\left(\mathrm{L}^{*}\right)$ would decrease along with fermentation time. It occurs due to proteolysis during fermentation which affects lightness in cheese (Todaro et al., 2017). The colour of cheese made of high-fat and high-beta carotene colostrum is more yellow. During ripening, free water content evaporates so carotene-containing fat would spread evenly. It was in line with (Pinho et al., 2004) that water evaporation has increased fat content that fills the cavity where the water has escaped. This process could increase the yellowish or reddish color in cheese which spread evenly, but the lightness and whiteness index would decrease the longer the ripening time. The increasingly yellow color in cheese is a good characteristic as it could improve cheese flavor and consumers' preference because acidic cheese tends to exhibit white color due to 
high protein agglomeration; hence, high lightness (Sádlíková et al., 2010; Talbot-Walsh et al., 2018).

\section{Microstructure of Cheese}

Microstructure significantly affects the physical and chemical properties of cheese. Cheese made of different raw material exhibits different microstructure, particularly the distribution of casein matrix (Figure 1). Components such as the fat and water escape during the sample preparation process; therefore, the solid texture is the protein matrix. The dark cavities in the matrix are air pockets that initially contain fatty cells or serum that have undergone sublimation, or the former water or alcohol from the fermentation using yeast starter. Paz et al. (2017) reported that the globular fat milk is responsible to form round space or cavities in the cheese protein matrix. Big lumps of protein resulted from the combined matrix during curdling which forms a compact matrix.

Figure 1 (cheese A) shows a large aggregate protein with a few cavities, cheese $\mathrm{B}$ has more cavities, and cheese $\mathrm{C}$ is similar to B only with bigger cavities. It reflects a higher fat content in milk to make cheese $\mathrm{B}$ and $\mathrm{C}$ than $\mathrm{A}$; therefore, there are more and bigger cavities in cheese $\mathrm{C}$ than A and B. This result supported (Everett and Auty, 2017) that fat cheese is a small, $2 \mu \mathrm{m}$ globular while the size of aggregate globular is $10-50 \mu \mathrm{m}$ that looks like a hole trapped in the protein matrix. According to Farbod et al. (2015), cheese made of high-fat raw material has more cavities than low-fat. Big cavity observed in microstructure is formed during yeast fermentation using kefir starter to make the cheese

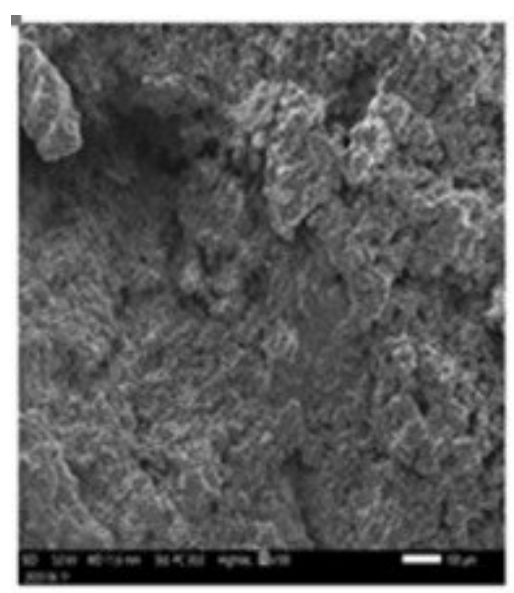

A

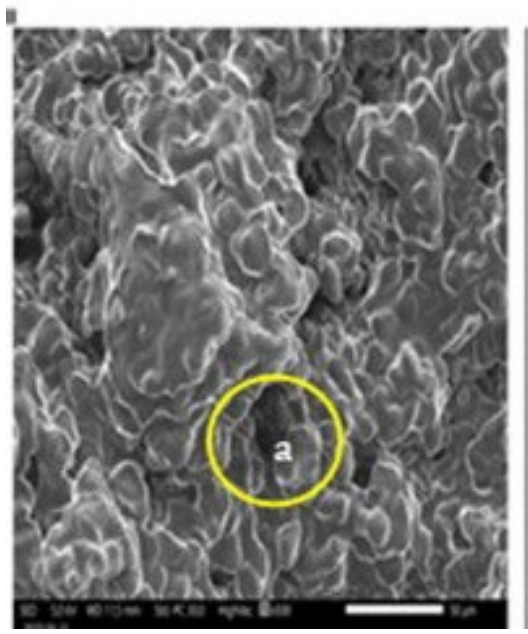

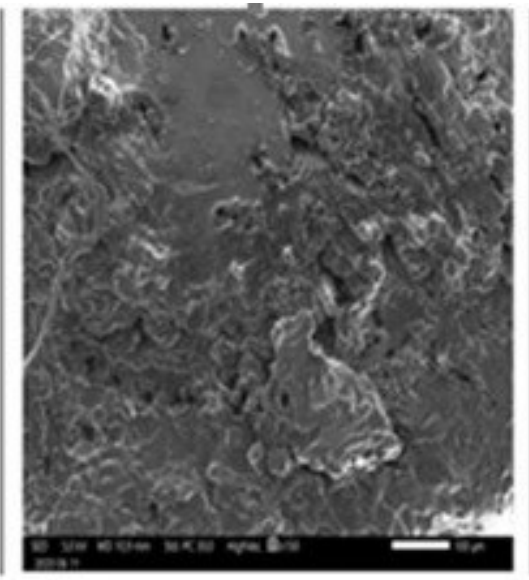

B

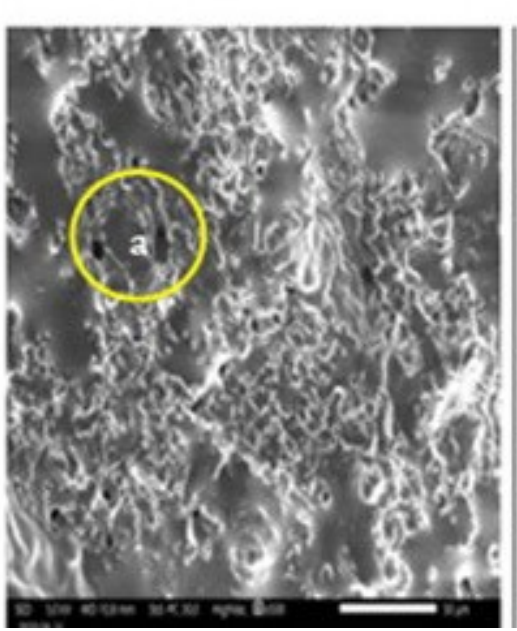

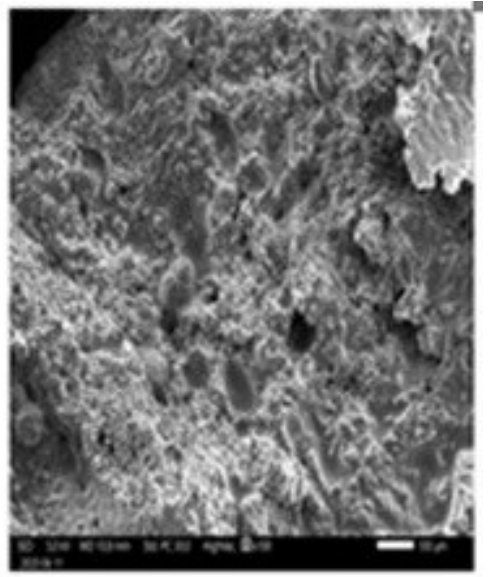

C

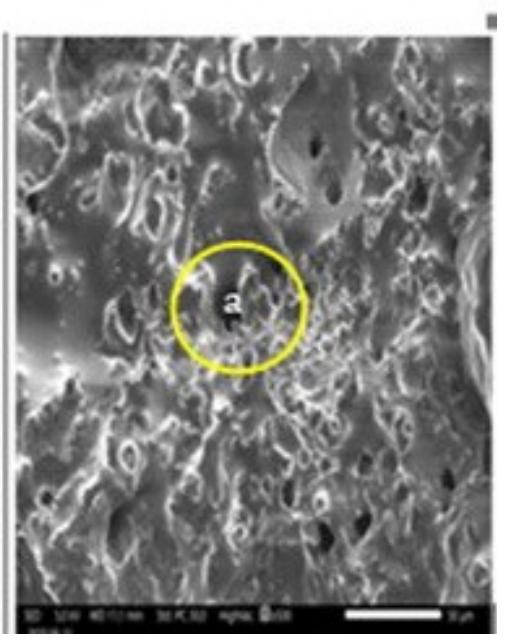

Figure 1. Figure 1. Microstructure of Cheese Before Ripening $\mathrm{A}=$ cheese made from $100 \%$ cow milk), $\mathrm{B}=$ cheese made from (50\% cow milk $+50 \%$ colostrum) and $\mathrm{C}=$ cheese made from $100 \%$ colostrum. Top image at $100 \mathrm{x}$ magnification; bottom image at $500 \mathrm{x}$ magnification. $\mathrm{a}=$ dark cavities/voids 
In acidic conditions, the yeast would produce alcohol as well as gas, so cavities or cavities are formed when the cheese is pressed. Farbod et al. (2015) mentioned that the size of the cavity in cheese is attributed to fat, water, and gas produced during the ripening process that includes glycolysis, lipolysis and proteolysis.

\section{CONCLUSION}

The characteristics of cheese color (lightness, whiteness index and yellowness) and cheese texture (hardness and gumminess) have varying effects on the raw material of the cheese. Incubation time affects all physical characteristics of cheese, except for the yellowness and cohesiveness.

\section{ACKNOWLEDGMENTS}

The authors express their sincere gratitude to the Provincial Government of Central Java for the research grant contract number 894.1/581/2018 as well as all related stakeholders in this study.

\section{REFERENCES}

Al-Baarri, A. N. M., A. M. Legowo, S. K. Arum and S. Hayakawa. 2018. Extending shelf life of indonesian soft milk cheese (dangke) by lactoperoxidase system and lysozyme. Int. J. Food Sci. Article ID 4305395: 1-7

El-Nimr, A., H. A. Eissa, M. El-Abd, A. Mehriz, H. M. Abbas and H. M. Bayoumi. 2010. Water activity, color characteristics and sensory properties of egyptian Gouda cheese during ripening. Am. J. Sci. 6 (10):447-453.

Everett, D. W. and M. A. Auty. 2017. Chemistry, physics and microbiology Cheese microstructure. p 547-569. Elsevier.

Farbod, F., A. Kalbasi, S. Moini, Z. EmamDjomeh, H. Razavi and A. Mortazavi. 2015. Effects of storage time on compositional, micro-structural, rheological and sensory properties of low fat Iranian UF-Feta cheese fortified with fish oil or fish oil powder. J. Food Sci. Technol. 52(3):1372-1382.

Godhia, M. L. and N. Patel. 2013. Colostrum-its Composition, Benefits as a Nutraceutical-A Review. J. Food Sci. Technol. 1(1):37-47.

Goncu, A. and Z. Alpkent. 2005. Sensory and chemical properties of white pickled cheese produced using kefir, yoghurt or a commercial cheese culture as a starter. Int.
Dairy J. 15(6):771-776.

Hyršlova, I., G. Krausová, J. Bartova, L. Kolesár and L. Čurda. 2016. Goat and bovine colostrum as a basis for new probiotic functional foods and dietary supplements. J. Microb. Biochem. Technol. 8(2):056-059.

Kourkoutas, Y., L. Bosnea, S. Taboukos, C. Baras, D. Lambrou and M. Kanellaki. 2006. Probiotic cheese production using Lactobacillus casei cells immobilized on fruit pieces. J. Dairy Sci. 89(5):1439-1451.

Mei, J., F. Feng, Q. Guo, Y. Li and Y. Wu. 2015. Evaluation of freeze-dried Tibetan kefir coculture as a starter for production of Bod ljong cheese. Food Sci Biotechnol 24(3): 1017-1027.

Nedomová, Š., L. Kilián, R. Pytel and V. Kumbár. 2017a. Effect of ripening time on colour and texture properties in cheese. S. J. F. Sci 11(1): 296-301.

Ong, L., R. R. Dagastine, M. A. Auty, S. E. Kentish and S. L. Gras. 2011. Coagulation temperature affects the microstructure and composition of full fat Cheddar cheese. Dairy Sci.Technol. 91(6):739-758

Paz, N. F., E. Goncalvez de Oliveira, F. J. Villalva, M. Armada and A. N. Ramón. 2017. Effect of $\mathrm{pH}$ at drainage on the physicochemical, textural and microstructural characteristics of mozzarella cheese from goat milk. Food Sci. Technol. 37(2):193-201.

Pecka-Kiełb, E., A. Zachwieja, E. Wojtas and W. Zawadzki. 2018. Influence of nutrition on the quality of colostrum and milk of ruminants. Mljekarstvo: časopis za unaprjeđenje proizvodnje i prerade mlijeka 68(3): 169-181.

Pinho, O., E. Mendes, M. Alves and I. Ferreira. 2004. Chemical, physical, and sensorial characteristics of "Terrincho" ewe cheese: changes during ripening and intravarietal comparison. J.Dairy Sci. 87(2):249-257.

Sádlíková, I., F. Buňka, P. Budinský, V. Barbora, V. Pavlínek and I. Hoza. 2010. The effect of selected phosphate emulsifying salts on viscoelastic properties of processed cheese. LWT-Food Sci.Technol. 43(8): 1220-1225.

Sadowska, J., I. Białobrzewski, T. Jelińskiand M. Markowski. 2009. Effect of fat content and storage time on the rheological properties of Dutch-type cheese. J. Food. Eng. 94(3-4): 254-259. 
Setyawardani, A. H. D. Rahardjo and M. Sulistyowati. 2017a. Chemical characteristics of goat cheese with different percentages of mixed indigenous probiotic culture during ripening. Trop. Anim. Sci. J. 40(3):55-62.

Setyawardani, T., A. H. D. Rahardjo and M. Sulistyowati. 2017b. Chemical characteristics of goat cheese with different percentages of mixed indigenous probiotic culture during ripening. Media Peternakan. 40(1):55-62.

Setyawardani, T., J. Sumarmono and K. Widayaka. 2019. Effect of cold and frozen temperatures on artisanal goat cheese containing probiotic lactic acid bacteria isolates (Lactobacillus plantarum TW14 and Lactobacillus rhamnosus TW2). Vet. World. 12(3):409-417.

Setyawardani, T., J. Sumarmono and K. Widayaka. 2020. Physical and microstructural characteristics of kefir made of milk and colostrum. Bul. Peternakan. 44(1):43-49

Shendi, E., A. Asl, A. Mortazavi, H. Tavakulipor, A. Ebadi and H. Afshari. 2010. The effect of Arabic gum using on improving of texture and rheological properties of Iranian low fat white cheese. Am Eurasian J. Agric. Environ. Sci. 8(5): 607-614.

Sołowiej, B., I. W. Cheung and E. C. Li-Chan. 2014. Texture, rheology and meltability of processed cheese analogues prepared using rennet or acid casein with or without added whey proteins. Int. Dairy J. 37(2):87-94.

Sumarmono, J., T. Setyawardani and S. A. Santosa. 2020. Effect of storage conditions on the characteristics and composition of fresh goat cheese containing probiotics. Anim. Prod. 21(1):56-63.

Talbot-Walsh, G., D. Kannar and C. Selomulya. 2018. A review on technological parameters and recent advances in the fortification of processed cheese. Trends Food Sci. Technol. 81: 193-202.

Todaro, M. 2017. Effect of refrigerated storage on microbiological, chemical and sensory characteristics of a ewes' raw milk stretched cheese. Food Packag. Shelf Life 11: 67-73.

Zheng, Y., Z. Liu and B. Mo. 2016. Texture profile analysis of sliced cheese in relation to chemical composition and storage temperature. J. Chem. 26(1):1-10. 